\title{
Assessment of the Water-Energy Nexus in the Municipal Water Sector in Eastern Province, Saudi Arabia
}

\author{
Homoud Al-Mutrafi'1 , Waleed Al-Zubari², Alaa El-Sadek², Ibrahim Abdel Gelil² \\ ${ }^{1}$ Research and Development Center, Saudi Aramco, Dhahran, Kingdom of Saudi Arabia \\ ${ }^{2}$ College of Postgraduate Studies, Arabian Gulf University, Manama, Kingdom of Bahrain \\ Email:waleed@agu.edu.bh, alaasa@agu.edu.bh
}

How to cite this paper: Al-Mutrafi, H., Al-Zubari, W., El-Sadek, A. and Gelil, I.A. (2018) Assessment of the Water-Energy Nexus in the Municipal Water Sector in Eastern Province, Saudi Arabia. Computational Water, Energy, and Environmental Engineering, 7, 1-26.

https://doi.org/10.4236/cweee.2018.71001

Received: October 16, 2017

Accepted: November 24, 2017

Published: November 27, 2017

Copyright $\odot 2018$ by authors and Scientific Research Publishing Inc. This work is licensed under the Creative Commons Attribution International License (CC BY 4.0).

http://creativecommons.org/licenses/by/4.0/

(C) (i) Open Access

\begin{abstract}
When it comes to water and energy, it is hard to obtain one without the other. Water is required to produce energy and energy is necessary in water production and management. As demands for water are escalating due to rapid population growth and urbanization, understanding and quantification of the interdependency between water and energy, along with analyzing nexus interactions, trade-offs and risks are a pre-requisite for effective and integrated planning and management of these two key sectors. This paper performs an assessment of the water-energy nexus in the municipal sector of the Eastern Province of Saudi Arabia, where the electric energy footprint in the water value chain (groundwater, desalination and wastewater treatment) and the water footprint in electric energy generation (thermal power plants) are quantified using data for the year 2013. The results confirmed the high and strong dependency on energy for the municipal water cycle in the Eastern Province and revealed that energy generation dependency on freshwater resources is also major and evident, especially at farther distances from the coastal areas. Thermal desalination is by far the most energy intensive stage among the entire Eastern Province water cycle. In 2013, it was estimated 13\% of the Eastern Province energy generation capacity goes for desalination, that's a $5 \%$ of the Kingdom capacity. Substantial energy input for desalination in the Eastern Province is attributed to the production and conveyance of water to the Capital Riyadh ( $48.9 \mathrm{kWh} / \mathrm{m}^{3}$ and $4.2 \mathrm{kWh} / \mathrm{m}^{3}$ respectively). As for groundwater pumping, it was estimated that $206.2 \mathrm{GWH}$ was used for pumping $268 \mathrm{MCM}$ in $2013\left(0.764 \mathrm{kWh} / \mathrm{m}^{3}\right)$. Energy requirement for primary, secondary and tertiary wastewater treatment was found to be the least $(2-108 \mathrm{GWH})$ and was equivalent to an average of $0.4 \mathrm{kWh} / \mathrm{m}^{3}$. The water footprint in electricity generation was estimated to be about 739,308 $\mathrm{m}^{3}$ in $2013\left(0.125 \mathrm{~m}^{3} / \mathrm{kWh}\right)$, a
\end{abstract}


relatively higher value compared to the norm of gas combustion turbine cooling water requirement around the world, and is especially significant for water scarce Kingdom. Anthropogenic Greenhouse Gases (GHG) emission was computed to be around 17 Million Ton of carbon dioxide equivalent $\left(\mathrm{CO}_{2 \mathrm{e}}\right)$ for the entire water supply chain, with desalination having the highest carbon footprint in the whole water cycle (16.9 MT of $\mathrm{CO}_{2 \mathrm{e}}$ ). Carbon emissions from electric energy generation through power plants had significantly exceeded the entire water supply chain's carbon footprint. Alternative mitigation options of management and technology fixes are suggested to reduce energy consumption in the water cycle, minimize the water footprint in electric generation, and mitigate associated GHG emission.

\section{Keywords}

Thermal Power Plant, Environmental Impact, Carbon Footprint, Energy Recovery, Management and Mitigation

\section{Introduction}

\subsection{Water-Energy Bond "the Nexus"}

The term "Water-Energy Nexus" is relatively a new concept, which emerged only during the last decade. In recent years, the topic has picked up a huge interest and popularity among the scientific communities and governments specifically [1] [2] [3]. The issue became a strategic policy for future planning and management of the growing water and energy challenges. It has been widely agreed upon and indicated in various publications within the literature that water and energy are co-evolving in a close relationship and are required to generate each other [1]-[12]. While energy is required in every stage of water production, i.e., water extraction, seawater desalination, wastewater treatment and water transportation; water is an essential requirement in energy production stages (Figure 1) whether directly such as hydropower or indirectly, i.e., power plant cooling, steam generation, refinery, gas possessing facilities and process additive like enhanced oil recovery [2] [6] [10] [13]. Moreover, even though renewable energy sources, or the so-called green energy alternatives, appear to have zero reliance on water as they do not require water for cooling, yet water is integrated during their life cycle [14]. For instance, although both wind turbines and solar panels-photovoltaic consume negligible amounts of water during the cleaning process, concentrating solar technology known as solar thermal is thought to consume approximately five times more water than a conventional gas fired power plant, twice as much water as coal fire power plant, and 1/2 times as much as a nuclear plant [8] [14].

To appreciate this inevitable relationship between water and energy even more, one could look at how much water is used to produce energy and how much energy goes into the water cycle. For example, the United States consumes 


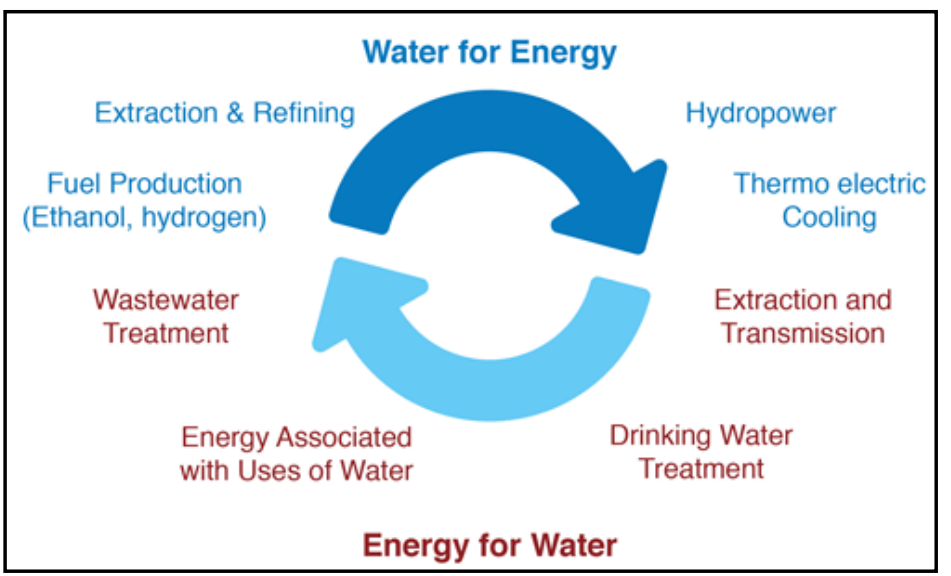

Figure 1. Water-energy nexus [15].

about 200 billion gallons of water per day (3.8 MCM), including seawater for cooling thermoelectric power plants which in turn provides more than $90 \%$ of the electricity in the USA, about 3500 million MWh [1]. In the Kingdom of Saudi Arabia, a staggering 25\% of its oil and gas production is consumed to produce fresh water through desalination processes; around $70 \%$ of the kingdom drinking water is provided through desalination plants located on both the Arabian Gulf and the Red sea [4] [16] [17]. Words such as interrelated, coupled, interdependency, intrinsically linked, inextricably linked, integrated, tied together, and two way connection have become distinctive characteristics to the majority of water-energy related publications and research papers in the literature [1] [2] [5] [6] [9] [11] [18]. This highlights the fact that these two fundamental elements are required to sustain the existence of each other and that they are linked in an intimate way and are profoundly interrelated. Several water-energy nexus evaluation and assessment academic studies carried out for different countries including USA, Spain, and China are described in [1] [18] [19] respectively. These experimental academic studies looked at the nexus in detail at a country level, and came up with useful outcome and recommended some legislations related to water-energy planning. Other attempts followed and were on a relatively larger scale. They looked at the issue from a bird eye view with the aim of mainstreaming the efforts and research put into the water-energy issue. For example, there have been some works carried on the Middle East and Northern Africa (MENA) region, the Arab region, Western Asia and the Gulf Cooperation Council (GCC) countries [3] [6] [7] [10] [11] [20].

\subsection{Objectives}

This interdependency or "nexus" (Figure 1) is becoming more apparent and important, especially when attempting to address the integrated management of water and energy resources specifically for countries which lack renewable freshwater resources such as Saudi Arabia. Like the rest of the GCC countries, Saudi Arabia is experiencing rapid population and urbanization growth, so- 
cio-economic and industrial development, all coupled with increasing standards of living, changing lifestyle and consumption patterns. The high per capita water and energy demands represent a critical issue for the Kingdom, which is considered severely poor in natural freshwater sources with already depleting nonrenewable fossil groundwater resources that are witnessing deterioration both in quality and quantity.

The ability of the Kingdom to bridge the water supply-demand gap by the fossil fuel-intensive desalination is considered unsustainable and could pose major risks to its socio-economic development, environment and human wellbeing. Thermal desalination is an energy intensive process, requires capital investment, and may be linked to air quality deterioration issues as well as marine environment impact if not planned, designed and managed properly. Thus, an understanding and an in-depth assessment of the water-energy interlinkages, trade-offs, and the risks they have on each other is required so these risks are mitigated and opportunities in resource efficiency and sustainability are identified. Despite the strong interlinkages and interdependencies, there is a knowledge gap in the water-energy nexus in Saudi Arabia, and the GCC in general, where country-specific quantitative data for the interdependency between water and energy is lacking. This data is very important in understanding the nexus nature and dynamics, which ultimately could be a very helpful tool in implementing an integrated water-energy planning and management approach, and increase policy coherence among the two sectors.

The main objective of the study is to bridge the water-energy nexus knowledge gap and to understand the current nexus relationship and dynamics in Saudi Arabia using the Eastern province as a case study. This is made by producing quantitative data that estimate how much energy goes into the water value chain and vice-versa under the current designed and operational conditions of Saudi Arabia. Data was gathered mainly from operating plants and published government documents, as well as related scientific literature. In addition, an estimate of the nexus associated environmental externalities in terms of greenhouse gases (GHGs) emission, an important policy parameter in light of the Kingdom commitment towards Paris 2015 climate change agreement, is made. Moreover, management alternatives to help optimize energy consumption in the water value chain and reduce water consumption in the energy generation sector, are explored and recommended to pave the way for formulating and implementing nexus management approach for the water and energy sectors at the country level.

\section{Study Area}

The kingdom of Saudi Arabia is located in the southwest corner of Asia, being an intersection between Europe, Asia and Africa continents (Figure 2). The Kingdom occupies over 2.15 million $\cdot \mathrm{km}^{2}$, which represents around $80 \%$ of the Arabian Peninsula with a total of 30 million inhabitants. The Eastern Province, 


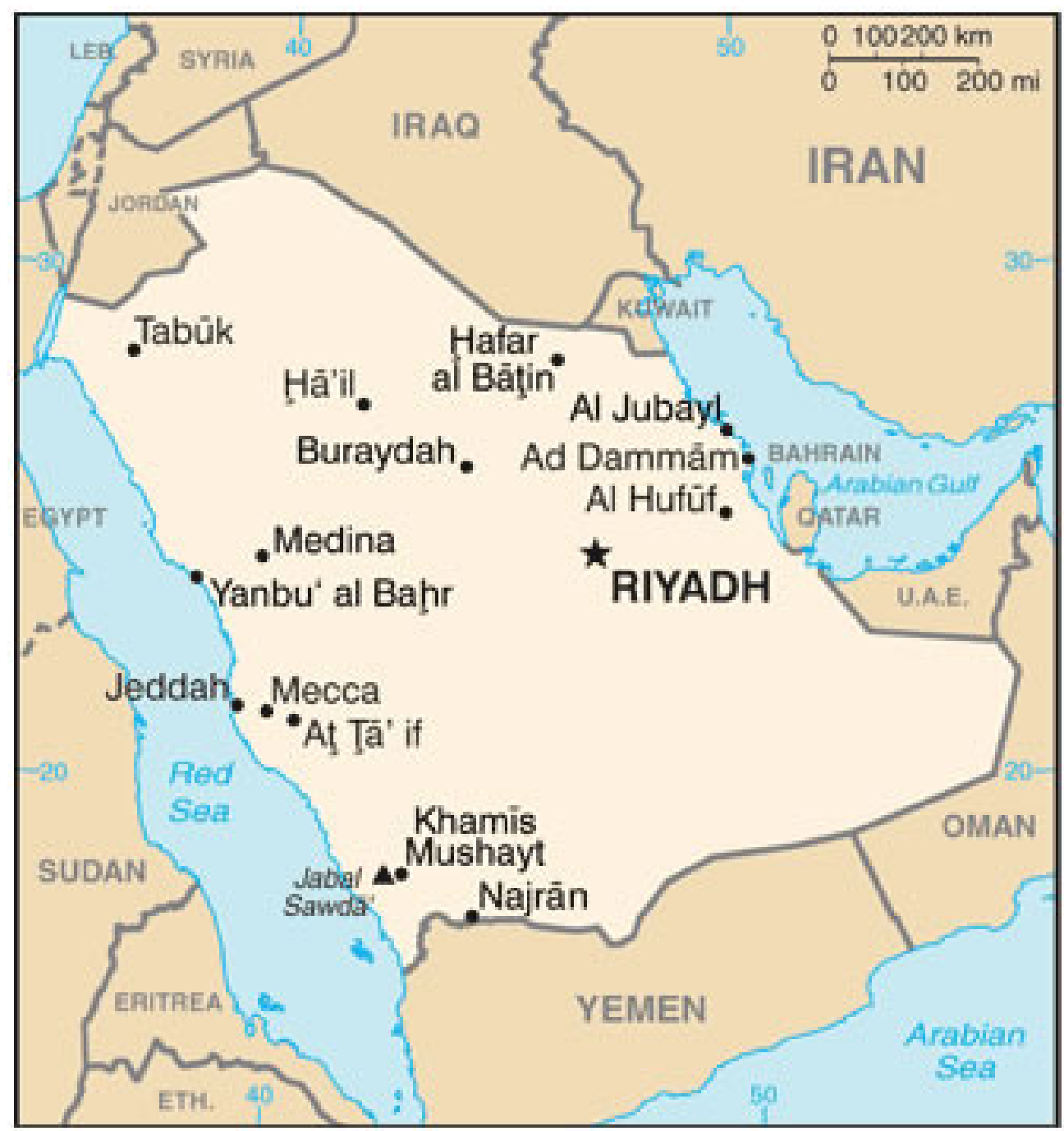

Figure 2. The kingdom of Saudi Arabia [22].

our case study, is of high importance economically, geographically and socially in the Kingdom among other provinces with a total area of $9900 \mathrm{~km}^{2}$. The Province includes around 23 councils and the major cities are Jubail, Dhahran, Dammam, Khobar, RasTanura, Qatif, Hassa and Khafji. The province is rich in oil and gas production among other petrochemical industries. In 2013, the total population in the Eastern Province was 4.65 million inhabitants. The population growth rate in the province is calculated at 3.7\% for the period 2004-2010 [21].

This paper focuses on the water-energy nexus in municipal sector of the Eastern Province. Its scope includes quantifying energy requirements in the urban water value chain (desalination and groundwater production, transmission and distribution, and wastewater treatment) and water requirements in electric energy production. The study uses the business year of 2013, for which complete data for the Eastern Province's water and energy use are available.

The Eastern Province water supply consists of conventional (groundwater) and unconventional (desalinated seawater and treated wastewater) water 
sources. In 2013 the total supplied water to the Eastern Province for the municipal sector from all water sources (groundwater and desalinated) is estimated at $599 \mathrm{Mm}^{3}$ [16] about $55 \%$ of this volume was supplied by desalinated seawater and the remaining $45 \%$ by groundwater. During this year about $234 \mathrm{Mm}^{3}$ of treated wastewater was reused, which represented about $25 \%$ of the total treated wastewater volume of $345 \mathrm{Mm}^{3}\left(945,205 \mathrm{~m}^{3} /\right.$ day) for the same year. Table 1 summarizes the municipal water supply for the year 2013 in the Eastern Province.

Saudi Arabia is considered the world leading desalination country possessing about $17 \%$ of the world total desalination capacity [23]. In 2013, seawater desalination capacity in 2013 exceeded 1 Billion $\cdot \mathrm{m}^{3}$ registering a $5.4 \%$ increase compared to 2012 production (about $955 \mathrm{Mm}^{3}$ ). Table 2 provides desalination plant specifications, including process type, production design capacity as well as the cities they serve in Eastern Province.

Groundwater used to supply municipal sector water requirements in the Eastern Province is withdrawn from three main aquifers, from top to bottom: Neogene, Dammam, and Umm ErRadhuma. These aquifers have varying salinity levels and they are supplied either directly (rare cases) or blended with desalinated

Table 1. Eastern province municipal water supply and demand in 2013 [16].

\begin{tabular}{cc}
\hline Demand, $\mathrm{Mm}^{3}$ & 599 \\
Demand growth rate (2006-2013) & 2.9 \\
Desalination contribution, \% & 55 \\
Groundwater contribution, \% & 45 \\
Treated wastewater, $\mathrm{Mm}^{3}$ & 345 \\
Reused treated wastewater, \% & 25 \\
Per capita municipal water consumption, $\mathrm{m}^{3}$ & 129 \\
\hline
\end{tabular}

Table 2. Breakdown of eastern province seawater desalination production in 2013 [16] [24].

\begin{tabular}{|c|c|c|c|c|}
\hline City & $\begin{array}{c}\text { Supplied } \\
\text { water } \mathrm{Mm}^{3}\end{array}$ & $\begin{array}{l}\text { Technology } \\
\text { used }\end{array}$ & Plant name & $\begin{array}{l}\text { Total supplied } \\
\qquad \mathrm{Mm}^{3}\end{array}$ \\
\hline & 32 & MSF & Jubail MSF $1 \& 2$ & \\
\hline Jubail & 2.5 & MED & $\begin{array}{c}\text { IWPP } \\
\text { MARAFIQ }\end{array}$ & 34.5 \\
\hline Khafji & 7.5 & MSF & Khafji MSF $2^{\text {nd }}$ & 7.5 \\
\hline $\begin{array}{c}\text { Damamm, } \\
\text { Khobar, Qatif, } \\
\text { Dhahran, Safwa, } \\
\text { Siyhat, Ras } \\
\text { Tanura, Abqaq } \\
\text { and Hufof }\end{array}$ & 161 & MED & $\begin{array}{c}\text { Khobar } \\
\text { MSF } 2 \& 3 \\
\text { IWPP } \\
\text { MARAFIQ }\end{array}$ & $\begin{array}{l}281 \text { (Eastern } \\
\text { Province Grand } \\
\text { total } 323 \mathrm{MCM} \text { ) }\end{array}$ \\
\hline Riyadh & $\begin{array}{l}306.5 \\
28.5\end{array}$ & MSF & $\begin{array}{c}\text { Jubail } \\
\text { MSF } 1 \& 2 \\
\text { Jubail RO }\end{array}$ & $\begin{array}{c}335 \text { (Riyadh Grand } \\
\text { total } 335 \mathrm{MCM})\end{array}$ \\
\hline
\end{tabular}


water. Table 3 provides some of the characteristic of groundwater in the Eastern Province.

Treated municipal wastewater (TWW) is another important unconventional water source in the Kingdom, although it is currently underutilized. In 2013, the Kingdom reused only $14 \%$ (181 MCM) of its treated wastewater (1261 MCM) with a daily treatment average of $3.5 \mathrm{MCM}$ in the whole Kingdom. Most wastewater treatment plants in the Eastern Province have tertiary stage treatment levels.

In regards to the energy in Saudi Arabia, electric energy is generated strictly through thermal power plants jointly by Saudi Electric Company (SEC) and Saline Water Conversion Cooperation (SWCC) with a small contribution from other small private companies. Percentages of electric energy production in the Kingdom by producers (SEC, SWCC and others) are shown in Figure 3. Table 4 summarizes the total number of thermal plants in the Kingdom, their production capacities and their owner (producer).

Table 3. Eastern province principle groundwater aquifers, recharge rate and quality [25].

\begin{tabular}{ccccc}
\hline Aquifer & $\begin{array}{c}\text { Reserve } \\
\left(\mathrm{Mm}^{3}\right)\end{array}$ & $\begin{array}{c}\text { Recharge } \\
\left(\mathrm{Mm}^{3} / \mathrm{Yr}\right)\end{array}$ & TDS (mg/L) & $\begin{array}{c}\text { Average } \\
\text { depth }(\mathrm{m})\end{array}$ \\
\hline Dammam & 45,000 & 200 & $2600-6000$ & \\
Neogene & 130,000 & 360 & $2400-4000$ & 218 \\
Umm ErRadhuma & 190,000 & 406 & $2000-5000$ & \\
\hline
\end{tabular}

Table 4. Capacities of generation units of licensed entities [26].

\begin{tabular}{ccc}
\hline Producing entity & Number of plants & $\begin{array}{c}\text { Production capacity } \\
\text { (Megawatt) }\end{array}$ \\
\hline $\begin{array}{c}\text { Saudi Electric Company (SEC) } \\
\text { Saline Water Conversion }\end{array}$ & 46 & 51,525 \\
Cooperation (SWCC) & 6 & 5018 \\
Others & 24 & 13,218 \\
Total & 76 & 69,761 \\
\hline
\end{tabular}

${ }^{*}$ Others include: Saudi Aramco, Jubail Water and Electricity Company, Tihamah Power Generation Company, Shuaibah Water and Electricity Company, MARAFIQ-Yanbu' and other small firms.

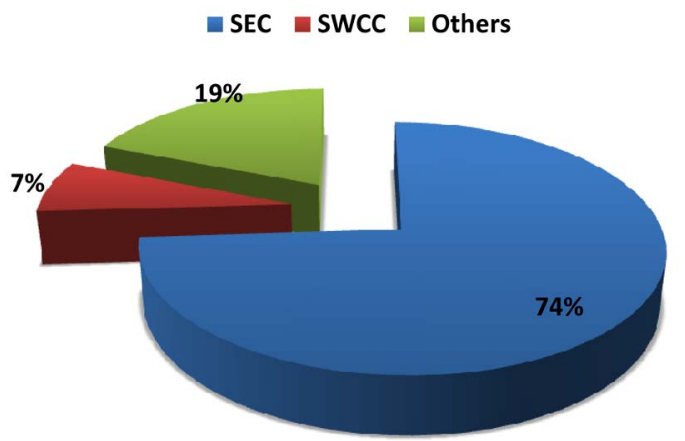

Figure 3. Distribution of generation capacities among producers [26]. 
The majority of SEC power plants in the Kingdom use natural gas as their primary fuel. Per capita electricity consumption has been rising steadily in Saudi Arabia. In 2013, per capita electricity consumption in the Kingdom was 8.37 MWH. Per capita consumption in the Eastern Province is higher than the Kingdom average and was $13 \mathrm{MWH}$ during the same year.

\section{Materials and Methods}

The method employed is a case study using the Eastern Province current water-energy data for linear analysis of water-energy interdependency. The data pertain to Eastern Province is mainly gathered from water-energy authorities in Saudi Arabia to compute and estimate energy intensity in the water value chain (for groundwater, desalination and wastewater treatment); water intensity in energy generation (mainly power plants) and GHG emissions from the water-energy nexus in the Eastern Province during the business year of 2013. The following sections quantitatively estimate energy input in the water value chain in the form of electric energy and water requirements in energy production stage and thus projecting each segment of the water-energy nexus in the study area.

\subsection{Energy for Water}

For water cycle, the energy intensity (input) will be expressed in kilowatt-hours per cubic meter of water produced $\left(\mathrm{kWh} / \mathrm{m}^{3}\right)$. The water cycle will be discussed in this research includes:

a) Groundwater Pumping;

b) Seawater Desalination (Operation and Water Transmission) and;

c) Wastewater Treatment WWT (Operation).

1) Groundwater

The electric energy requirement for pumping groundwater will be determined using a theoretical physical relationship equation to establish energy requirement for pumping a mass of water as described in [27]. The equation formula is shown below:

$$
\operatorname{Energy}(\mathrm{kWh})=\frac{9.8 \mathrm{~m} \cdot \mathrm{s}^{-2} \times \operatorname{Lift}(\mathrm{m}) \times \operatorname{Mass}(\mathrm{kg})}{3.6 \times 10^{6} \times \operatorname{Efficiency}(\%)}
$$

where:

$9.8 \mathrm{~m} / \mathrm{s}^{2}=$ Gravitational constant $(\mathrm{g})$;

Lift $=$ depth or distance of moving water vertically $(\mathrm{m})$ (average for Eastern Province $=218 \mathrm{~m}$ );

Mass $=$ Mass of water in kilograms $\left(1 \mathrm{~m}^{3}\right.$ of water has $1000 \mathrm{~kg}$ of mass $)$;

$3.6 \times 10^{6}=$ Conversion factor from work (in joules) to energy in $(\mathrm{kWh})$;

Efficiency $=$ The effectiveness of pumping process measured in (\%) average for Eastern Province (77\%).

Typically the above equation is divided by pump efficiency (\%). Assuming $100 \%$ efficiency of the process (no energy loss; $100 \%$ efficient pump). From the equation, it can be established that the energy required to lift $1 \mathrm{~m}^{3}$ of water 
(having the mass of $1000 \mathrm{~kg}$ ) a distance of $1 \mathrm{~m}$ vertically is $0.0027 \mathrm{kWh}$ [28]. This finding is also described in [29] "The energy needed to lift $1000 \mathrm{~m}^{3}$ of water a distance of 1 meter is $2.724 \mathrm{kWh}$ with no efficiency losses" using the same mathematical relationship equation. Therefore, Energy to lift $1 \mathrm{~m}^{3}$ with $100 \%$ pump efficiency is $2.724 / 1000=0.002724 \mathrm{kWh} / \mathrm{m}^{3}$ with $50 \%$ efficiency its $0.002724 / 0.50=0.00554 \mathrm{kWh} / \mathrm{m}^{3}$ and so on. This factor $(0.0027 \mathrm{kWh})$ can be divided by pump efficiency (\%) and multiplied by the value of groundwater depth i.e., say $120 \mathrm{~m}$ aquifer with $50 \%$ pumping efficiency; $0.0054 \times 120=0.648 \mathrm{kWh}$ for each $\mathrm{m}^{3}$ of water withdrawn (lifted or supplied to the demand) with an assumed 50\% pumping efficiency. Consequently, the following equation will be employed in the case study to determine the energy intensity in groundwater pumping at Eastern Province with assumed efficiency of $77 \%$ (the average pumps efficiency) and average wells depth of $218 \mathrm{~m}$.

Energy requirements for groundwater pumping $=\left[\mathrm{kWh}\right.$ to lift $1 \mathrm{~m}^{3}$ of water 1 $\mathrm{m} /$ Pumping efficiency \%] $\times$ Depth of Groundwater $(\mathrm{m}) \times$ Volume of water lifted $\left(\mathrm{m}^{3}\right)$ in 2013$]=[0.00353 \mathrm{kWh} \times 218 \mathrm{~m} \times$ Volume of Groundwater Water $\mathrm{Ab}$ stracted in 2013].

2) Desalination

When it comes to desalination, there are two types of electric energy consumption that are taken into consideration, namely: energy for operation (desalination process both thermal and electrical) and energy for water transmission (water transport from desalination plants to end users "cities"). The below sections will review each stage energy intensity estimation procedure.

\subsubsection{Desalination Process Operation}

The electric energy requirements for Eastern Province desalination plants that will be employed in this case study are based on value directly obtained from SWCC through direct commutation with the corporation operation representatives and the published literature described in [30] [31]. Table 5 shows typical SWCC Eastern Province desalination plants Specific Energy Consumption (SEC) (which include thermal and electric energies) to treat $1 \mathrm{~m}^{3}$ of seawater, including MSF, MED and RO.

The following equation will be employed in the case study to determine the energy intensity for seawater desalination operation:

Specific Electric Energy Requirement in Desalination $=$ [Desalination Technology Specific Energy Consumption $($ SEC) $\times$ Desalinated Water Volume in $2013\left(\mathrm{~m}^{3}\right)$ From Plant Using that Technology].

Table 5. Eastern province desalination plants energy consumption.

\begin{tabular}{cccc}
\hline $\begin{array}{c}\text { Desalination } \\
\text { technology }\end{array}$ & $\begin{array}{c}\text { Energy requirements } \\
\left(\mathbf{k W h} / \mathbf{m}^{3}\right)\end{array}$ & $\begin{array}{c}\text { Total energy } \\
\left(\mathbf{k W h} / \mathbf{m}^{\mathbf{3}}\right)\end{array}$ & Reference \\
\hline MSF & Thermal (38); Electric (3.5) & 41.5 & {$[30]$} \\
MED-TVC & Thermal (38); Electric (1.5) & 39.5 & {$[30]$} \\
RO & Electric (7.4) & 7.4 & {$[31]$} \\
\hline
\end{tabular}




\subsubsection{Water Transmission}

Water transmission from desalination plants to Eastern Province major cities and the rest of the Kingdom is carried out through distinctive pipelines belong to SWCC. The energy used to transmit water is a function of energy used to transport $1 \mathrm{~m}^{3}$ of water $1 \mathrm{~m}$ horizontally multiplied by pipeline length. Estimating this type of energy is often a challenge since not all pipelines are exactly the same in shape, size or length. Also, topography could play a major role in energy required to transport the water to end users. for example, transporting water uphill from Eastern Province to the nearest suburbanize of capital Riyadh across more than $500 \mathrm{~km}$ where ground is elevated more (more than $500 \mathrm{~m}$ above sea level), typically consumes more energy than transporting water to Eastern Province cities that are on the same level of elevation, i.e., Khobar to Damamm. With the absence of detailed technical data of the pipelines and topography uncertainty could be significant. Therefore, energy consumption of the water transport is obtained from SWCC as per electric bills issued by SEC and paid by authorities of SWCC. Table 6 shows energy consumption of pipelines in water transmission in the Eastern Province provided by SWCC Khobar Plant. SWCC has only recently begun assessing, and auditing this segment of water value chain energy consumption. Therefore, data capture of water transmission aspect will improve with time and may vary.

As per Table 6, energy is calculated in $\mathrm{kWh}$ per day. Therefore, to estimate energy intensity required to transport $1 \mathrm{~m}^{3}$ of water to Eastern Province cities the following formula will be used:

Water Transport Energy Consumption $=$ [Annual Energy Consumption of Water Transmission/Annual Supplied Water].

Energy requirement for water transmission to Riyadh area is reported by [32] in an energy footprint study of coastal seawater desalination with substantial lift and long distance conveyance verses brackish water RO inland. Table 7 and will

Table 6. Eastern province desalinated water transport energy consumption (courtesy of SWCC Khobar Plant, 2014).

\begin{tabular}{cccccc}
\hline \multicolumn{5}{c}{ Power consumption in kWh/Day } \\
\hline Pipeline 05 & Pipeline 06 & Pipeline 07 & Pipeline 08 & B/S & EP-PS \\
\hline 57 & 83 & 656 & 312 & 82,557 & 687,336 \\
Total & & $771,001.07 \mathrm{kWh}$ per day $=281,415,389 \mathrm{kWh}$ per year \\
\hline
\end{tabular}

${ }^{\star}$ EP-PS $=$ Eastern Province Pumping Stations; B/S = Blending Stations; Pipeline 5 \& 6 = Eastern Province Stage 2 Pipeline; Pipeline 7 = Khobar-Hofuf Pipeline; Pipeline $8=$ Eastern Province Stage 1 Pipeline.

Table 7. Riyadh area water provision from desalination plants at Arabian Gulf with substantial lift and distance.

\begin{tabular}{cccc}
\hline Arabian Gulf to Riyadh & Distance 700 km & $\begin{array}{c}\text { Elevation (Lift) } \\
700 \mathrm{~m}\end{array}$ & Reference \\
\hline Energy requirement & $1.6-2.0 \mathrm{kWh} / \mathrm{m}^{3}$ & $2.2-2.6 \mathrm{kWh} / \mathrm{m}^{3}$ & {$[32]$} \\
Average & $1.8 \mathrm{kWh} / \mathrm{m}^{3}$ & $2.4 \mathrm{kWh} / \mathrm{m}^{3}$ & \\
\hline
\end{tabular}


be utilized to compute energy requirements for Riyadh desalinated water transmission.

3) Wastewater Treatment (WWT)

Energy used in WWTP is mainly for pumping either effluent or air among other usages such as mixing or chemical dosage. Typically, in the Eastern Province wastewater is collected through gravity flow in sewer system to wastewater plants. In the Eastern province WWTPS are either activated sludge or advanced WWTP. The energy of WWT process is often dependent on plant size, level of treatment and technology employed. Because of various settings and designs among other technical aspects of WWTPs, a detailed energy requirement for WWTPs is often overlooked or not readily available. Consequently, no energy consumption data is available on WWTPs in the Eastern Province or the Kingdom of Saudi Arabia. Nevertheless, the energy consumption values of WWTP processes are presented in Table 8 are applicable for different geographic regions of the world. Since WWTP in the Eastern Province are mostly standard activated sludge (biological treatment) these data are the best available estimate to energy intensity of WWT and are used/accepted widely in litterateur in calculating WWTP energy requirements. Therefore, the methodology to estimate WWTP energy consumption in Eastern region will adopt the same set of data as per plant size.

The following equation will be employed in the case study to determine the energy intensity for wastewater treatment operation:

Energy requirements in WWTP $=\left[\mathrm{kWh} / \mathrm{m}^{3}\right.$ as per technology and WWTP Size from Table] $\times$ [Treated Wastewater Volume in $\left.2013 \mathrm{~m}^{3}\right]$.

\subsection{Water for Energy}

Water is a necessary resource in energy production stages as discussed earlier. Specifically, energy generation in the form of electric energy production is dependent on water availability. Mainly water is used for cooling purposes in electric energy production or in some cases for moving turbine as in hydropower. Broadly, Eastern Province relies on thermoelectric plants in energy generation utilizing both techniques, Gas Turbine (GT) and Steam Turbine (ST). Unlike

Table 8. WWTP energy consumption according plant size [33].

\begin{tabular}{cccc}
\hline \multirow{2}{*}{$\begin{array}{c}\text { Plant size } \\
\text { (cubic meters } \\
\text { per day) }\end{array}$} & Primary & $\begin{array}{c}\text { Electric energy consumption }\left(\mathrm{kWh} / \mathrm{m}^{3}\right) \\
\text { (activated sludge) }\end{array}$ & $\begin{array}{c}\text { Tertiary (advanced } \\
\text { WW treatment) }\end{array}$ \\
\hline 3785 & 0.479 & 0.59 & 0.686 \\
18,925 & 0.258 & 0.362 & 0.416 \\
37,850 & 0.255 & 0.318 & 0.372 \\
75,700 & 0.198 & 0.294 & 0.344 \\
189,250 & 0.182 & 0.278 & 0.321 \\
378,500 & 0.177 & 0.272 & 0.314 \\
\hline
\end{tabular}


other places in the world, Saudi Arabia does not depend on water for direct energy generation (hydropower) thus energy produced in Saudi Arabia is strictly driven via thermal plants. Thermal power plants water consumption is highly dependent on cooling technology employed and of high water consumption specially for cooling. Quantifying water consumption at a given power plant is a complex deal and is plant specific. Moreover, there are no available or captured data on water consumption of thermal power plants in the Eastern Province provided by literature. Therefore, the only reliable method to estimate water input in electric energy production of the Eastern Province power plants was to obtain the available data directly from SEC and the corresponding power plants. Acquired SEC available water consumption data that will be utilized to qualitatively estimate water intensity in electric energy production domain at the case study. Table 9 shows Eastern Province gas and steam power plants, their cooling technology employed, water source, and their respective monthly water consumption values obtained from SEC where data available. Data shown in Table 9 will be employed in the subject case study.

The following equation will be employed in the case study to determine the water intensity for electric energy production at thermal power plants $\left(\mathrm{m}^{3} / \mathrm{MW}\right)$ after which the result can be expressed in $\left(\mathrm{m}^{3} / \mathrm{kWh}\right)$ : Water requirements in Thermal Power Plants $=\left[\right.$ Annual Water Use $\left(\mathrm{m}^{3}\right) /$ Annual Energy Production (Megawatt)].

\section{Accounting for Externalities (GHG and Marine Environmental Impact)} GHG emission will be computed using average of $\mathrm{CO}_{2}$ values reported in literature for Natural Gas since the dominant fuel type used to produce electric energy is Natural Gas in the Kingdom and strictly in Eastern Province. Natural gas emission factor ( $605 \mathrm{~g} \mathrm{CO}_{2 \mathrm{e}} \mathrm{kWh}$ ) will be employed in the case study as all water cycle in the Eastern Region is driven via natural gas thermal power plants and in the same time all Eastern Province power plant are fed by the same fuel (Table 10).

Table 9. Eastern province thermal power plant cooling technology \& water consumption [34].

\begin{tabular}{cccc}
\hline Power plant & Type of cooling & Water type & $\begin{array}{c}\text { Water consumption } \\
\mathrm{m}^{3} / \mathrm{month}\left(\mathrm{m}^{3} / \text { day) }\right.\end{array}$ \\
\hline Ghazlan-I power plant & Open loop cooling & Seawater & N.A \\
Qurayyah power plant & Open loop cooling & Seawater & N.A \\
Shedgum power plant & Closed loop cooling & Groundwater & $125,670(4189)$ \\
Faras power plant & Closed loop cooling & Groundwater & $96,669.2(3222.3)$ \\
Berri power plant & Closed loop cooling & Groundwater & $24,641.1(821.3)$ \\
Uthmaniyah power plant & Closed loop cooling & Groundwater & $41,890(1396.3)$ \\
Ju'aymah power plant & Closed loop cooling & Groundwater & $14,960.7(498.6)$ \\
Jubail MSF & Open loop cooling & Seawater & N.A \\
Khobar MSF & Open loop cooling & Seawater & N.A \\
\hline
\end{tabular}

${ }^{*}$ In closed loop cooling system water is used to cool Lub Oil \& $\mathrm{H}_{2}$ Generator. 
Table 10. Summary of $\mathrm{CO}_{2}$ emission rate reported in literature in $\mathrm{g} \mathrm{CO}_{2 \mathrm{e}} / \mathrm{kWh}$.

\begin{tabular}{|c|c|c|c|}
\hline \multirow{2}{*}{ Reference } & \multicolumn{3}{|c|}{ Fuel type } \\
\hline & Coal & Oil & Natural gas \\
\hline$[35]$ & 1006 & 742 & 466 \\
\hline$[36]$ & $750-1250$ & $500-1200$ & $360-780$ \\
\hline [37] & 975.2 & 742.1 & $518.8-607.6$ \\
\hline [38] & $949-1280$ & $519-1190$ & $485-991$ \\
\hline [39] & 1004 & - & 543 \\
\hline$[40]$ & 1005.2 & 212.03 & 432.96 \\
\hline$[41]$ & - & - & $485-990$ \\
\hline Sample size & 8 & 7 & 11 \\
\hline Average & 1022.9 & 779.6 & $605.9=605,000 \mathrm{~kg} / \mathrm{GWH}$ \\
\hline
\end{tabular}

\section{Results and Discussion}

The following sections discuss the energy input in the water value chain and the water input in the energy generation in details as well as GHG emission.

\subsection{Energy for Water}

1) Groundwater

In 2013, energy requirement for groundwater pumping to provide $45 \%$ of the total municipal water supply is estimated to be about $206 \mathrm{GWH}$ using an average pumping efficiency of $77 \%$. It worth mentioning that should the pump efficiency increase to $83 \%$, the energy requirement for groundwater pumping will be in the dropped to $192 \mathrm{GWH}$.

2) Desalination

MSF is by far the most energy intensive process among other desalination technologies in the Eastern Province with energy consumption reaching 19,339 GWH in 2013 representing 74\% of total energy input in seawater desalination. Further to desalination operation, the energy requirement for the transmission of desalinated water to the province cities is shown in Table 11. Transporting desalinated water to Eastern Province cities (end users) is considered of low energy intensity $\left(0.87 \mathrm{kWh} / \mathrm{m}^{3}\right)$ in comparison with desalination operation and amounted to about 281.4 GWH in 2013. The Riyadh water transmission energy requirement is higher. This is because conveying water to the Riyadh area consists of long distance water transmission of over $500 \mathrm{~km}$ and elevation around $700 \mathrm{~m}$ above sea level, which has the potential to swing the energy requirements of desalinated water transmission and desalination as a whole. Conveying water to the capital Riyadh required $1407 \mathrm{GWH}\left(4.2 \mathrm{kWh} / \mathrm{m}^{3}\right)$, which is five times the energy required to transport and convey desalinated water to the Eastern Province major cities. Transporting desalinated water to Riyadh consumed more energy than RO desalination plant (210 GWH) dedicated to supplying water to Riyadh. The electric energy consumption of water production through desalination is shown in Table 12 and the electric energy consumption of desalination operation and transmission is shown in Table 13. 
Table 11. Energy footprint of seawater desalination for the eastern province and Riyadh, in Gigawatt-hour.

\begin{tabular}{cc}
\hline Stage & GWH (\% of total) \\
\hline Eastern Province product water & $13,078(50.3 \%)$ \\
Riyadh product water & $12,931(49.7 \%)$ \\
Total seawater desalination in Eastern Province & 26,009 \\
\hline
\end{tabular}

Table 12. Electric energy consumption of water production through desalination at eastern province according to technology employed, in GWH.

\begin{tabular}{cc}
\hline Desalination technology & Gigawatt (\% of total) \\
\hline Multistage flash distillation (MSF) & $19,339(74.4 \%)$ \\
Multiple effect distillation (MED) & $6458(24.8 \%)$ \\
Reverse osmosis (RO) & $211(0.8 \%)$ \\
Total & 26,008 \\
\hline
\end{tabular}

Table 13. Electric energy consumption of desalination operation and transmission, in Gigawatt-hour.

\begin{tabular}{ccc}
\hline Process & Gigawatt (\%) & $\mathrm{KWH} / \mathrm{m}^{3}$ \\
\hline Desalination operation & 25,977 & $\begin{array}{c}41.5-39.5-7.4 \\
\text { (MSF, MED, RO) }\end{array}$ \\
$\begin{array}{c}\text { Desalination transmission to Eastern Province Cities } \\
\text { Desalinated water transmission to Riyadh }\end{array}$ & 281 & 0.87 \\
$\quad$ Total transmission (to Eastern & 1407 & 4.2 \\
$\quad$ Province Cities and Riyadh) & 1688 & 5 \\
Total desalinated water production and transmission & 27,665 & \\
\hline
\end{tabular}

\section{3) Wastewater Treatment ( WWT)}

Wastewater treatment processes including primary, secondary and tertiary plants energy requirements were estimated to be relatively insignificant and are shown in Table 14.

Figure 4 shows the energy consumption in the water value chain (groundwater, desalination and WWTPs) in 2013 in the Eastern Province. Desalination is by far the dominant energy consumer in the whole water value chain of the Eastern Province, especially the MSF technology followed by MED technology. Therefore, the desalination sector offers a prime aspect of a promising area of improvement that any energy efficiency technologies, process optimization, management plans and R\&D should target in the Eastern Province.

\subsection{Water for Energy}

The water footprint embedded in electric energy production (thermal gas power plants) in the Eastern Province represented primarily by cooling water and was determined to be about 3.6 MCM in 2013 (Figure 5) used mainly from shallow aquifers. Water intensity for the assessed power plants is presented in Table 15 
Table 14. WWTPs electric energy consumption in the Eastern Province, in GWH.

\begin{tabular}{ccc}
\hline & Gigawatt & $/ \mathrm{m}^{3}$ \\
\hline Primary treatment & 7.0 & 0.56 \\
Secondary treatment (activated sludge) & 2.1 & 0.36 \\
Tertiary treatment & 108.2 & 0.53 \\
Total wastewater treatment & 117.4 & 1.45 \\
\hline
\end{tabular}

Table 15. Water intensity for power plants in eastern province.

\begin{tabular}{cccccc}
\hline Plant & $\begin{array}{c}\text { Design } \\
\text { capacity }\end{array}$ & $\begin{array}{c}\text { Water usage } \\
\left(\mathrm{m}^{3} / \mathrm{y}\right) \mathbf{2 0 1 3}\end{array}$ & $\begin{array}{c}\text { Production } \\
\mathbf{M W H}\end{array}$ & $\mathrm{m}^{3} / \mathbf{M W H}$ & $\begin{array}{c}\text { Average } \\
\mathrm{m}^{3} / \mathbf{M W H}\end{array}$ \\
\hline Shedgum power plant & 1429.5 & $1,508,040^{*}$ & $12,522,420$ & 0.120 & \\
Faras power plant & 1058.7 & $1,160,030$ & $9,274,212$ & 0.125 & \\
Berri power plant & 278.1 & $295,693.2$ & $2,436,156$ & 0.121 & 0.125 \\
'Uthmania power plant & 412.2 & 502,680 & $3,610,872$ & 0.139 & \\
Juaymah power plant & 169.5 & $179,528.4$ & $1,484,820$ & 0.120 & \\
\hline
\end{tabular}

${ }^{*}$ Data obtained from SEC directly, data originally was in the form of $\mathrm{m}^{3} /$ month of cooling water-Plants shown are only available data.
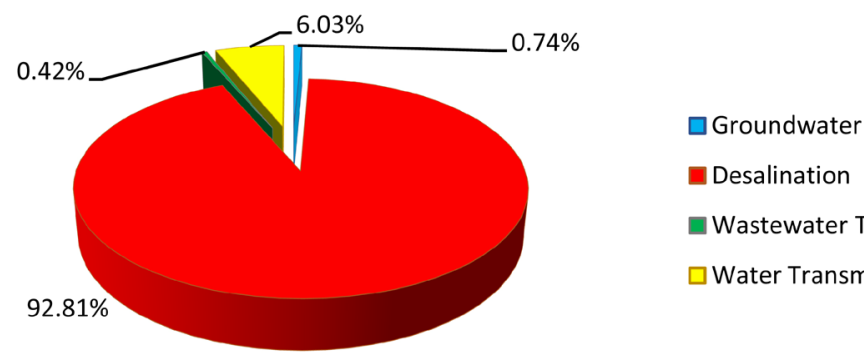

Wastewater Treatment

$\square$ Water Transmission

Figure 4. Water value chain (groundwater, desalination and WWTPs) electric energy consumption in 2013 at the eastern province, in GWh and percentage.

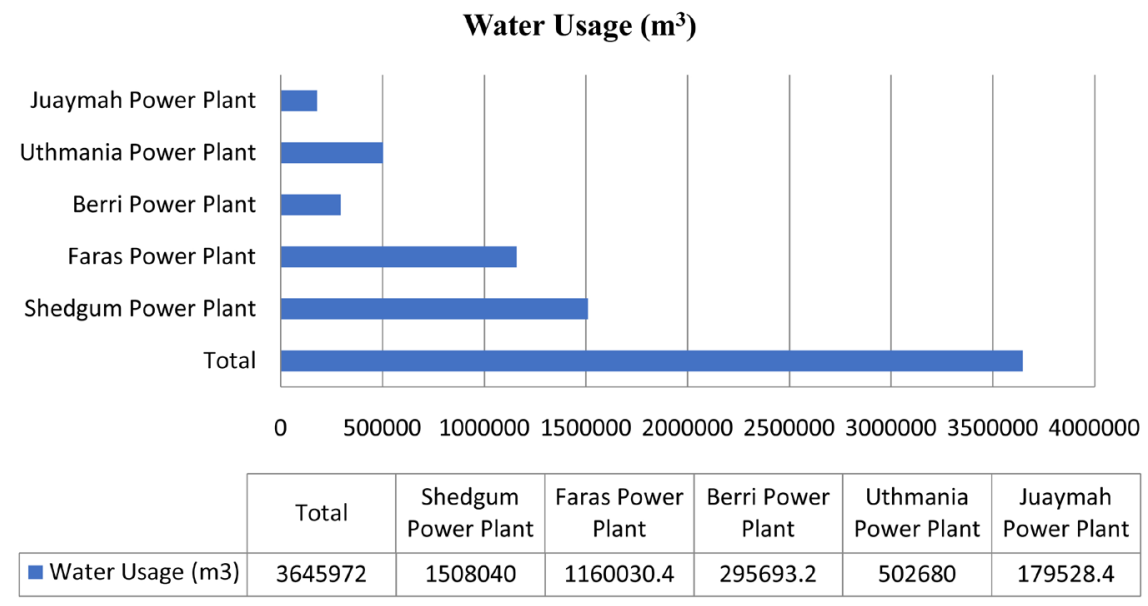

Figure 5. Cooling water requirements in thermal power plants of the eastern province.

and averaged $0.125 \mathrm{~m}^{3} / \mathrm{kWh}$. This is marginally higher than other values reported in the literature [12] for cooling, which is considered as "negligible". In 
the case of Saudi Arabia, this water is of high value due to the fact that it is obtained from non-renewable groundwater, placing further pressures on an already stressed groundwater. Probably, this represents a water conservation opportunity should this water be replaced with other non-conventional water sources, such as treated wastewaters, of which reuse potential has not been fully utilized.

\subsection{Externalities-Carbon Footprint}

Carbon dioxide $\left(\mathrm{CO}_{2}\right)$ emission associated with the water supply chain in the Eastern Province is represented in Table 16, Desalination is the principal dominant carbon emitter through the entire water supply chain; about 16.8 million tons of carbon dioxide equivalent $\left(\mathrm{CO}_{2 \mathrm{e}}\right)$ are attributed to desalination in the Eastern Province. Table 17 breaks down $\mathrm{CO}_{2 \mathrm{e}}$ emission as per technology used in the entire water production value chain in the Eastern Province. It is clear that plants using MSF technology are the highest contributor to $\mathrm{CO}_{2 \mathrm{e}}$ emission.

The carbon footprint in energy production (power plants) is shown in Table 18. Thermal power plants evidently had significantly higher emissions compared to water industry as carbon emission from power plants is approximately 3000

Table 16. $\mathrm{CO}_{2 \mathrm{e}}$ emissions from Eastern province water value chain, in million tons.

\begin{tabular}{cc}
\hline Water source & Million tons $\mathrm{CO}_{2 \mathrm{e}}(\%)$ \\
\hline Desalination & $16.76(98.9 \%)$ \\
Groundwater & $0.12(0.7 \%)$ \\
WWTP & $0.07(0.4 \%)$ \\
Total & 16.95
\end{tabular}

Table 17. Breakdown of $\mathrm{CO}_{2 \mathrm{e}}$ emission as per Technology used in the entire water production value chain in the eastern province (2013), in million tons.

\begin{tabular}{ccc}
\hline Water value chain component & Million tons & $\%$ \\
\hline MSF & 11.700 & 69.02 \\
MED & 3.907 & 23.05 \\
Total desalination & 0.128 & 0.76 \\
Transmission Eastern Province & 15.735 & $\mathbf{9 2 . 8 2}$ \\
Transmission Riyadh & 0.170 & 1.00 \\
Total transmission & 0.851 & 5.02 \\
Primary wastewater treatment & 1.021 & 6.02 \\
Secondary wastewater treatment & 0.004 & 0.02 \\
Tertiary wastewater treatment & 0.001 & 0.01 \\
Total wastewater treatment & 0.065 & 0.38 \\
Groundwater pumping & 0.071 & 0.42 \\
Total water value chain & 0.125 & 0.74 \\
\hline
\end{tabular}


Table 18. Electric power plants $\mathrm{Co}_{2}$ emission in eastern province (2013 design capacity), in billion tons $\mathrm{CO}_{2 \mathrm{e}}$.

\begin{tabular}{cc}
\hline Plant & Billion tons $\mathrm{CO}_{2 e} \cdot$ \\
\hline Ghazlan power plant & 22.56 \\
Qurayyah power plant & 13.25 \\
Shedgum power plant & 7.58 \\
Faras power plant & 5.61 \\
Berri power plant & 1.47 \\
'Uthmaniyah power plant & 2.18 \\
Dammam power plant & 2.96 \\
Qaisumah power plant & 0.82 \\
Safaniah power plant & 0.50 \\
Ju'aymah power plant & 0.90 \\
Total & 57.83 \\
\hline
\end{tabular}

times the entire water supply chain's carbon emission in the Eastern Province.

The energy footprint (in the form of electric energy) in the water value chain in the municipal sector, namely: groundwater, desalination, transmission and wastewater treatment in the Eastern Province and water requirement for energy generation (electricity) for the year 2013 are summarized in Table 19. On average, the energy input in the whole municipal water cycle amounts to about 91.5 $\mathrm{kWh} / \mathrm{m}^{3}$, while water requirement in thermal power plants is about 0.125 $\mathrm{m}^{3} / \mathrm{kWh}$. The results indicate that in the municipal sector the water-energy nexus relationship is highly skewed with a relatively weak dependence of energy systems on fresh water, but a strong dependence of water systems on energy (however, it should be noted that this might not be true if the whole energy production system is taken into account; e.g., related to oil production in the Eastern Province).

Generally speaking around $15 \%$ of eastern region electric generation goes to water production including desalination, WW treatment and groundwater pumping, a relatively higher value compared with figure reported by Saddiqi and Anadon (2011), which was around 9\%. Nonetheless, Saddiqi and Anadon work did not stated WW to be part $\mathrm{f}$ the $9 \%$ value, also the figure was Kingdom wide.

\section{Proposed Mitigations Measures}

Based on the above quantification of the water-energy nexus in the Eastern Province, it can be concluded that under the current technological and management approaches the energy footprint for water production (mainly through the energy-intensive thermal desalination) is considerably high. The water footprint in energy generation and the reliance on non-renewable groundwater for cooling is alarming. These footprints are expected to increase with time along with the Kingdom's population and industrialization trends. A number of mitigation measures to lower these footprints from both management and technology 
Table 19. Eastern province water value chain energy requirements and water input in electricity generation in 2013.

\begin{tabular}{ccc}
\hline \multicolumn{2}{c}{ Water value chain } & Energy requirements $\mathrm{kWh} / \mathrm{m}^{3}$ \\
\hline Stage & Process & Energy range/(average) \\
\hline 1) Groundwater & Pumping & 0.764 \\
& MSF & 41.5 \\
2) Desalination & MED & 39.5 \\
& RO & 7.4 \\
& Transmission & 0.87 \\
3) Wastewater & Primary & $0.255-0.258(0.56)$ \\
treatment & Secondary & 0.362 \\
& Tertiary & $0.314-0.75(0.532)$ \\
Energy production (electricity) & $0.125 \mathrm{~m}^{3} / \mathrm{kWh}$ \\
\hline
\end{tabular}

perspectives have been proposed and investigated, as follows:

1) Raising Conservation Awareness and Water Saving Devices

According to [16], raising public awareness on water conservation could reduce consumption by $10 \%$, while water saving devices, which are being distributed for free, could save up to $20 \%$ of water uses in the municipal sector. A successful deployment and implementation of both measures would reduce the per capita consumption in the Eastern Province from 129 to $91 \mathrm{~m}^{3}$. If the year 2013 is taken as a base for savings calculation, this would be translated into a savings of about 4.4 million tons, 4.2 million tons and 375 metric tons of GHG emission $\left(\mathrm{CO}_{2 \mathrm{e}}\right)$ arising from desalination (MSF), (MED), and groundwater operation, respectively. More than 8 million tons of $\left(\mathrm{CO}_{2 \mathrm{e}}\right)$ could have been avoided and mitigated should these policies are made and put in place. Such measure would be relatively easily implemented through intensified conservation campaign specifically through new media venues and only if social acceptance and cooperation are present.

2) Brackish Water Reverse Osmosis Desalination for Riyadh Municipal Water Supply

The provision of water to Riyadh by RO desalination of brackish groundwater under and near the city (BWRO) is significantly more energy efficient as it requires less energy $\left(4.4 \mathrm{kWh} / \mathrm{m}^{3}\right)$ compared to the current coastal Seawater RO (SWRO) $\left(11.6 \mathrm{kWh} / \mathrm{m}^{3}\right)$ or MSF $\left(45.7 \mathrm{kWh} / \mathrm{m}^{3}\right)$ used to provide water to Riyadh taking into account both the energy requirements for each desalination technology and the substantial distance this water has to travel. Moreover, such switch to BWRO would result in tremendous GHG emissions reduction amounting to about 6 million tons of $\mathrm{CO}_{2 \mathrm{e}}$ as well as lower the impact on the marine environment. The disposal of the reject of the proposed BWRO would pose an environmental problem, in that it can pollute groundwater resources, and disposal needs to be properly designed and mitigated. More importantly, in such approach a tradeoff between energy/carbon saving and groundwater sustainability 
exists. Serious scrutiny and thorough planning have to be made before such exchange could prove feasible and viable. A comprehensive risk assessment of groundwater sustainability along uncertainty analysis are required to judge the applicability of such option to provide the capital Riyadh with water. The reliance on groundwater may be not sustainable if compared with seawater desalination as groundwater reserve is not renewed easily, still this approach could help partially but not entirely in water-energy nexus management venue. For example some part of Riyadh area could be better off being reliant on this water provision method, say $50 \%$ of Riyadh area.

\section{3) Hybrid Desalination}

The hybrid desalination system configuration (MSF/RO) (Figure 6) offers various operational flexibility, economical, energy and environmental advantages which could further lower both SWRO and MSF energy requirements and increase water recovery along with GHG emission reduction, thereby minimizing the potential marine environmental impacts. Hybrid desalination systems have a large potential to bring major advantages to the current desalination practices as demonstrated in [42] [43] to allow further optimization of desalination energy requirements. Such configuration already implemented in Jubail plant, yet further evaluation and efficiency enhancement of the system may be required in order to replicate such design elsewhere in the Kingdom and adopting a full hybridization instead of simple current hybrid MSF-RO system in the Eastern Province Jubail plant. Furthermore, acceleration and support of the examination of the tri-hybrid NF/MSF/RO configuration would further enhance desalination operation. It should not escape the decision makers in technology oversight sector that membrane (RO) and thermal (MED) desalination technologies are of

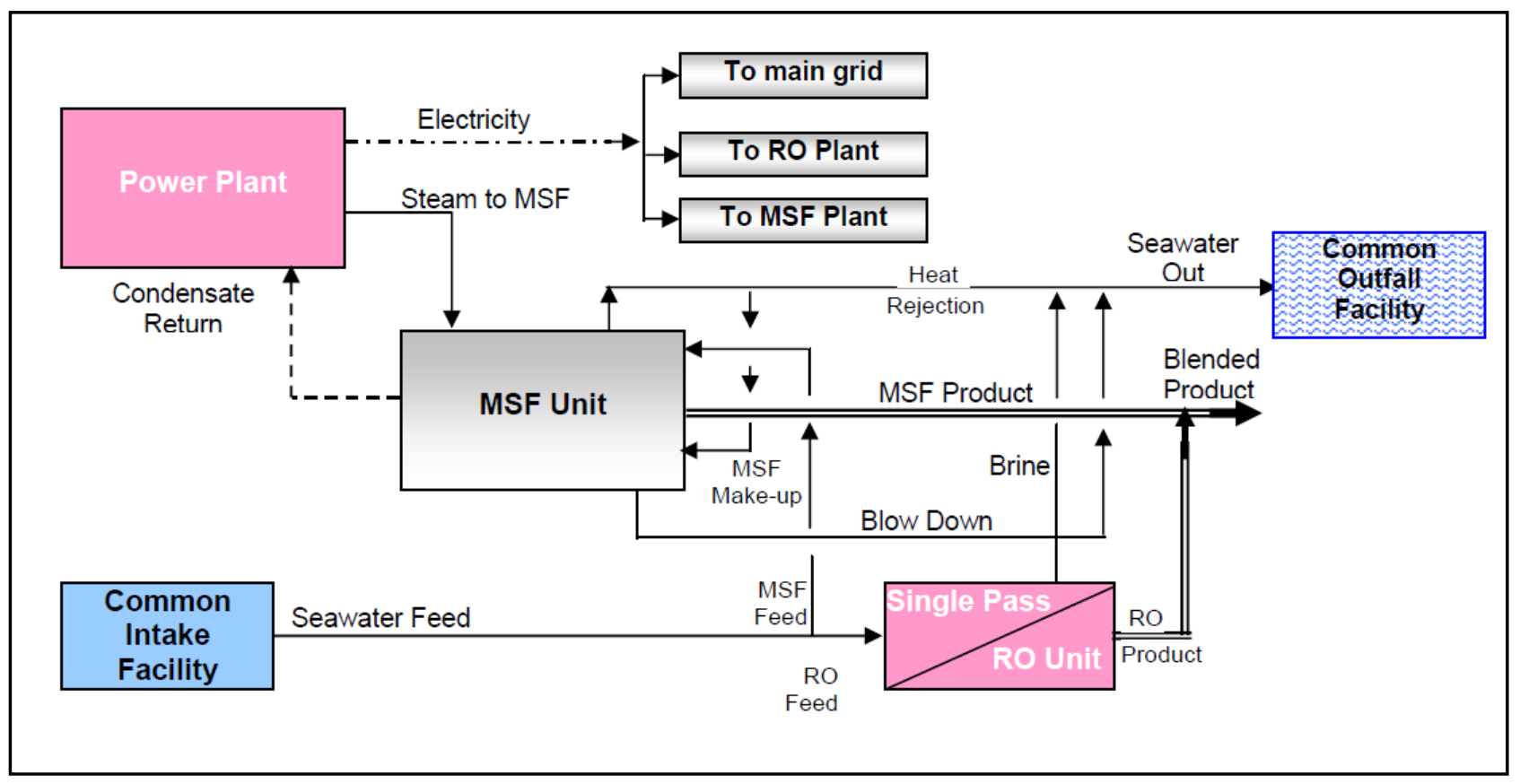

Figure 6. Simple hybrid MSF/RO configuration [42]. 
less energy consumption compared with typical MSF, thus there should be a shift towards these type of technologies in the future, which in turn would offset carbon emission and conserve energy.

4) Renewable Energies

A water cycle driven by renewable energy has a major potential in Saudi Arabia, as well as in the other GCC countries, due to the abundance of renewable resources, particularly solar, wind, and geothermal. Using solar desalination to produce water is a very attractive option as it provides relatively free clean energy, reduces the carbon footprint and minimizes fossil fuel desalination. Solar desalination could be a promising avenue to Saudi Arabia in general and the Eastern Province in particular. This is because MSF, MED or RO could be driven through solar energy. Using CSP to directly heat MSF or MED is proven to be inefficient [43]. The best configuration was found to be solar RO driven by photovoltaic cells. Furthermore, the use of CSP to generate power with steam extracted to MSF/MED (partially using some of the steam to drive MSF or MED) has potential and is a viable option [43]. Solar panel efficiency and cost may be the limiting factors for implementing such option, yet promising work is being done to tackle both aspects, thus making this alternative a viable option in future for the Kingdom. Furthermore, in the case of coastal desalination investigating the utilization of renewable energy (preferably solar) in water transmission operation to Riyadh from coastal desalination (RO) is recommended. This is because transporting water to Riyadh has a higher energy footprint than coastal seawater RO desalination energy requirements.

\section{5) Treated effluent as coolant in power plants}

First, not all treated wastewater in the Eastern Province is reused. A large amount of tertiary treated wastewater is discharged into the Arabian Gulf or some shallow bays, which represents a major lost opportunity under the water scarcity conditions of Saudi Arabia. Secondly, water requirements for cooling in energy generation plants are considered to be high if compared with global consumption values. Consequently, the use of treated wastewater effluent substitution as a coolant medium in thermal power plants offers great potential in reducing the water demand for cooling, which currently appears to have an extra burden on the already depleted groundwater sources, thus serious consideration should be given to utilizing the currently wasted treated effluents.

\section{Conclusions}

As demonstrated in the case study of the Eastern Province, water and energy are strongly inter-linked in the municipal sector. Substantial energy goes into water production, specifically thermal MSF/MED desalination, which was revealed to be the most energy-intensive process and represents the majority of energy input in the water value chain (around $41 \mathrm{kWh} / \mathrm{m}^{3}$ ). Large volumes of water are being used in energy production. The Eastern Province thermal power plants are dependent on groundwater for cooling especially in the inland plants $(0.125$ 
$\mathrm{m}^{3} / \mathrm{kWh}$ ); coastal power plants are utilizing seawater for cooling and power generation. Furthermore, Riyadh water provision (through coastal desalination and conveyance) is a key feature of the water-energy nexus in the Eastern Province, which influences the nexus characteristics significantly. Riyadh desalinated water energy requirements are almost comparable to the entire Eastern Province water production energy requirements. The water supply and management is fully fossil fuel-energy dependent, and the region's water dependency on energy is more prevalent; GHGs emission associated with the current water cycle exceeded 15 million tons of $\mathrm{CO}_{2}$ equivalent, mainly attributed to thermal desalination, whereas energy generation through power plants has significantly surpassed water supply chain in terms of GHGs. The $\mathrm{CO}_{2}$ emission from the power plants was 3000 times that associated with the entire water cycle at the Eastern Province, reaching about 57 billion tons of $\mathrm{CO}_{2}$ equivalent. It was estimated that the energy requirement for the entire water cycle represents $5 \%$ of the Kingdom total electric generation capacity and a staggering $13 \%$ of the Eastern Province electric energy generation capacity. This was largely dominated by thermal desalination operation and transmission followed by groundwater pumping and lastly wastewater treatment plants operation. The water footprint in electric energy generation is found to be high for the available data on plants' water consumption compared with other similar gas-fired turbine power plants around the world. The water is mainly used for cooling and is extracted from brackish groundwater aquifers. The ability of the Kingdom to produce water and energy through fossil fuel burning is the main factor helping bridging the gap for water and energy demands. The potential long-term environmental sustainability are questionable and is of concern, which needs to be thoroughly assessed and mitigated through a strategic nexus approach implementation, and robust research and development. In Saudi Arabia, desalination is inevitable to meet the escalating municipal water supply. While desalination cannot be ruled out, it can be made more environmentally friendly through a number of mitigation alternatives that aim at increasing water use and use of renewable energies. Similarly, dependency on non-renewable groundwater for cooling in the energy sector need to be revisited and other sources of water such as tertiary treated wastewater, available at relatively large volumes and are unused, can be utilized for this process.

Under the current management policies and technical approaches, the energy footprint for water production is generally high. Similarly, the water footprint in energy generation and the reliance on none-renewable groundwater for cooling is alarming. These footprints are expected to increase with time along with the Kingdom's expected future population and industrialization growth trends. The water-energy nexus in the municipal segment is being influenced by a number of driving forces, the most important of which are population and urbanization growth, consumption patterns, and more importantly, management policies in the two sectors, which are primarily sectoral and are focusing on the supply-side 
of management. The results suggest that policy makers should explicitly consider energy implications in future municipal water demands. This will help in making more integrated decisions on water and energy infrastructure systems. It is crucial for the Kingdom to adopt a water-energy nexus approach with strong focus on demand management to achieve effective resources management, lower the risks they pose on each other, and to ensure the sustainability of both sectors. A national integrated water-energy strategy with the objective of meeting water demands with minimum energy input and vice-versa, and minimizing environmental externalities on the long run is needed.

\section{Acknowledgements}

The author would like to thank the Saudi water and electricity authorities for making this work possible.

\section{References}

[1] Webber, M. (2011) The Nexus of Energy and Water in the United States. AIP Conference Proceedings, 1401, 84-106. http://scitation.aip.org/content/aip/proceeding/aipcp/10.1063/1.3653847

[2] Stillwell, A., King, C., Webber, M., Duncan, I. and Hardberger, A. (2011) The Energy-Water Nexus in Texas. Ecology and Society, 16, 2.

http://www.ecologyandsociety.org/vol16/iss1/art2/ https://doi.org/10.5751/ES-03781-160102

[3] Siddiqi, A. and Anadon, D. (2011) The Water-Energy Nexus in Middle East and North Africa. Energy Policy, 39, 4529-4540.

https://wiki.zirve.edu.tr/sandbox/groups/economicsandadministrativesciences/wiki/ 78a0c/attachments/6b0dd/week5recommended4.pdf

[4] WWAP (United Nations World Water Assessment Programme) (2014) The United Nations World Water Development Report 2014: Water and Energy. UNESCO, Paris. http://www.unwater.org/publications/publications-detail/en/c/218614/

[5] WITW (Water in the West) (2013) Water and Energy Nexus: A Literature Review. A Joint Program of Stanford Woods Institute for the Environment and Bill Lane Center for the American West.

[6] Tabakovic, A. and Poci, E. (2012) Water and Energy Nexus in Middle East, North Africa, and the United States.

[7] ESCWA (Economic and Social Commission for Western Asia) (2012) Intergovernmental Consultative Meeting on the Water and Energy Nexus in the ESCWA Region. E/ESCWA/SDPD/2012/IC.1/2/REPORT.

[8] Glassman, D., Wucker, M., Isaacman, T. and Champilou, C. (2011) The Water-Energy Nexus; Adding Water to the Energy Agenda. A World Policy Paper, World Policy Institute.

http://www.worldpolicy.org/sites/default/files/policy_papers/THE\%20WATER-EN ERGY\%20NEXUS_0.pdf

[9] Keller, A., Tellinghuisen, S., Lee, C., Larson, D., Dennen, B. and Lee, J. (2010) Projection of California's Future Freshwater Requirements for Power Generation. Energy \& Environment, 21, 1-20. http://multiscience.metapress.com/content/438671232l76h611/fulltext.pdf?page=1 
https://doi.org/10.1260/0958-305X.21.2.1

[10] Khatib, H. (2010) The Water and Energy Nexus IN THE ARAB REGION. Arab Water Report: Towards Improved Water Governance.

[11] Granit and Löfgren (2010) Water and Energy Linkages in the Middle East, Regional Collaboration Opportunities, Stockholm International Water Institute (SIWI).

[12] Pate, R., Hightower, M., Cameron, M. and Einfeld, W. (2007) Overview of Energy-Water Interdependencies and the Emerging Energy Demands on Water Resources. Sandia National Laboratories, United States Department of Energy's National Nuclear Security Administration. http://amfarid.scripts.mit.edu/resources/Media/Pate2007.pdf

[13] Mielke, E., Anadon, L. and Narayanamurti, V. (2010) Water Consumption of Energy Resource Extraction, Processing, and Conversion. Belfer Center for Science and International Affairs. Harvard Kennedy School, Cambridge. http://belfercenter.ksg.harvard.edu/files/ETIP-DP-2010-15-final-4.pdf

[14] Meldrum, J., Anderson, S., Heath, G. and Macknick, J. (2013) Life Cycle Water Use for Electricity Generation: A Review and Harmonization of Literature Estimates. Environmental Research Letter, 8, Article ID: 015031.

[15] WBCSD (World Business Council for Sustainable Development) (2009) Water, Energy and Climate Change. A Contribution from the Business Community. http://www.worldwatercouncil.org/fileadmin/world_water_council/documents/pro grams_hydropolitics_sdgs/WaterEnergyandClimateChange.pdf

[16] MOWE (Ministry of Water and Electricity) (2013) Annual Report.

[17] AFED (Arab Forum for Environment and Development) (2014) Institutional Challenges for Water-Energy Nexus, Arab Perspective.

http://www.un.org/en/ga/president/68/pdf/sts/wsse-presentations/A-Najib_Saab-Fe b19.pdf

[18] Hardy, L., Garrido, A. and Juana, L. (2012) Evaluation of Spain's Water-Energy Nexus. International Journal of Water Resources Development, 28, 151-170.

http://oa.upm.es/15641/1/INVE_MEM_2012_129724.pdf https://doi.org/10.1080/07900627.2012.642240

[19] Kahrl, F. and Roland-Holst (2008) China's Water-Energy Nexus. Water Policy, 10, 51-65. http://are.berkeley.edu/ dwrh/CERES_Web/Docs/Cn_H2O_Erg_KRH080109.pdf

[20] Zubari, W. (2013) The Water-Energy Nexus in the GCC Countries Evolution and Related Policies. Sixth Zayed Seminar on Green Economy: Success Stories from the GCC, Arabian Gulf University. http://www.agu.edu.bh/pdf/sixthzayedseminar/Second\%20Day/5/Waleed\%20Zubar i.pdf

[21] CDSI (Central Department of Statistics and Information) (2013) Social and Demographic Statistical Report. http://www.cdsi.gov.sa/english/

[22] Ezilon Maps (2015). https://www.ezilon.com/maps/asia/saudi-arabia-maps.html

[23] Almulla, Y. (2014) Modelling Electricity and Water Desalination Demand in the Gulf Cooperation Council (GCC) Countries. MSc Thesis, KTH Industrial Engineering and Management, Sweden.

[24] SWCC (Saline Water Conversion Corporation) (2013) Annual Report. http://www.swcc.gov.sa/

[25] MOWE (Ministry of Water and Electricity) (2012) Supporting Documents for King Hassan II Great World Water Prize 2012. Nomination of Ministry of Water \& Elec- 
tricity Kingdom of Saudi Arabia.

http://www.worldwatercouncil.org/fileadmin/world_water_council/documents_old /Prizes/Hassan_II/Candidates_2011/16.Ministry_SA.pdf

[26] ECRA (Electricity and Cogeneration Regulatory Authority) (2013) Annual Report.

[27] Rothausen, S. and Conway, D. (2011) Greenhouse Gas Emissions from Energy Use in the Water Sector. Nature Climate Change, 1, 210-219.

http://www.nature.com/nclimate/journal/v1/n4/pdf/nclimate1147.pdf https://doi.org/10.1038/nclimate1147

[28] Wang, J., Sabrina, G., Conway, D., Zhang, L., Xiong, W., Holman, I. and Li, Y. (2012) China's Water-Energy Nexus: Greenhouse-Gas Emissions from Groundwater Use for Agriculture. Environmental Research Letters, 7, Article ID: 014035. http://sourcedb.cas.cn/sourcedb_igsnrr_cas/zw/lw/201203/P02012031949756513843 $\underline{0 . p d f}$ https://doi.org/10.1088/1748-9326/7/1/014035

[29] Nelson, G., Robertson, R., Msangi, S., Zhu, T., Liao, X. and Jawajar, P. (2009) Greenhouse Gas Mitigation; Issues for Indian Agriculture, The International Food Policy Research Institute (IFPRI). http://ebrary.ifpri.org/cdm/ref/collection/p15738coll2/id/23497

[30] Al-Alshaikh, A. (2014) A Comparison between MSF \& MED Desalination Technologies. Presentation at the 2nd Saudi International Water Technology Conference.

[31] Farooque, A., Jamaluddin, A., Al-Reweli, A., Jalaluddin, P., Al-Marwani, S., Al-Mobayed, A. and Qasim, A. (2004) Comparative Study of Various Energy Recovery Devices Used in SWRO Process. SWCC Technical Report No. TR.3807/EVP 02005 .

http://www.swcc.gov.sa/files/assets/Research/Technical\%20Papers/Reverse\%20Osm osis/COMPARATIVE\%20STUDY\%20OF\%20VARIOUS\%20ENERGY\%20RECOV ERY\%20DEVICES\%20USED\%20IN.pdf

[32] Sobhani, R., Abahusayn, M., Gabelich, C. and Rosso, D. (2012) Energy Footprint Analysis of Brackish Groundwater Desalination with Zero Liquid Discharge in Inland Areas of the Arabian Peninsula. Desalination, 291, 106-116. http://www.sciencedirect.com/science/article/pii/S001191641200080X

[33] EPRI (Electric Power Research Institute) (2002) Water and Sustainability: U.S. Electricity Consumption for Water Supply and Treatment. http://www.circleofblue.org/waternews/wp-content/uploads/2010/08/EPRI-Volume -4.pdf

[34] SEC (Saudi Electricity Company) (2014) Direct Communication with Dammam Headquarter.

[35] Meier, P., Wilson, P., Kulcinski, G. and Denholm, P. (2005) US Electric Industry Response to Carbon Constraint: A Life-Cycle Assessment of Supply Side Alternatives. Energy Policy, 33, 1099-1108.

http://www.researchgate.net/publication/223635765_US_electric_industry_respons e_to_carbon_constraint_A_life-cycle_assessment_of_supply_side_alternatives

[36] Weisser, D. (2007) A Guide to Life-Cycle Greenhouse Gas (GHG) Emissions from Electric Supply Technologies. Energy, 32, 1543-1559. http://www.sciencedirect.com/science/article/pii/S036054420700028X

[37] Hondo, H. (2005) Life Cycle GHG Emission Analysis of Power Generation Systems: Japanese Case. Energy, 30, 2042-2056. 
http://www.sciencedirect.com/science/article/pii/S0360544204003652

[38] Dones, R., Heck, T. and Hirschberg, S. (2003) Greenhouse Gas Emissions from Energy Systems: Comparison and Overview. Energy, 100, 2300.

http://www.iaea.org/inis/collection/NCLCollectionStore/_Public/36/002/36002859.pdf

[39] Evans, A., Strezov, V. and Evans, T. (2009) Assessment of Sustainability Indicators for Renewable Energy Technologies. Renewable and Sustainable Energy Reviews, 13, 1082-1088.

http://www.sciencedirect.com/science/article/pii/S1364032108000555

[40] USEPA (U.S. Environmental Protection Agency) (2010) Greenhouse Gas Emissions Data.

[41] Dones, R., Heck, T., Emmenegger, M. and Jungbluth, N. (2005) Life Cycle Inventories for the Nuclear and Natural Gas Energy Systems, and Examples of Uncertainty Analysis. The International Journal of Life Cycle Assessment, 10, 10-23.

http://www.researchgate.net/publication/226889697_Life_Cycle_Inventories_for_th e_Nuclear_and_Natural_Gas_Energy_Systems_and_Examples_of_Uncertainty_An alysis_(14_pp)

https://doi.org/10.1065/lca2004.12.181.2

[42] Hamed, O. (2014) Overview of Hybrid Desalination Systems-Current Status and Future Prospects. Presented at "Chemistry \& Industry" Conference, King Saud University, Riyadh, 11-15 December.

http://www.swcc.gov.sa/files\%5Cassets\%5CResearch\%5CTechnical\%20Papers\%5CTher mal/OVERVIEW\%20OF\%20HYBRID\%20DESALINATION\%20SYSTEMS\%20-\%2 0CURRENT\%20STATUS\%20AND.pdf

[43] Darwish, M. and Khaleel, M. (2014) Towards Practical Implementation of Solar Desalination in GCC. Qatar Environment and Energy Research Institute, Presentation on the 5th Arab-German Energy Forum, Berlin. http://www.energy.ghorfa.de/fileadmin/inhalte/2014/PPP/Session\%202/s0203\%20D arwish_Arab\%20German\%20presentation\%20Nov13.pdf 


\section{List of Acronyms}

BWRO: Brackish Water Reverse Osmosis

$\mathrm{CO}_{2}$ : Carbon Dioxide

$\mathrm{CO}_{2 \mathrm{e}}$ : Carbon Dioxide Equivalent

CSP: Concentrated Solar Plant

ECRA: Electricity and Cogeneration Regulatory Authority

EOR: Enhanced Oil Recovery

ESD: Energy Saving Devices

ESCWA: Economic and Social Commission for Western Asia

GCC: Gulf Cooperation Countries

GT: Gas Turbine

GHG: Green House Gases

GWH: Gigawatt Hours

KSA: Kingdom of Saudi Arabia

KWh: Kilowatt-hour

$\mathrm{M}^{3}$ : Cubic meter

MED: Multi Effect Desalination

MENA: Middle East and Northern Africa

MOWE: Ministry of Water and Electricity

MSF: Multi Stage Flash

MT: Million Tons

MWh: Megawatt-hour

NF: Nano Filtration

PV: Photovoltaic Cells

RO: Reserves Osmosis

SEC: Saudi Electric Company

ST: Steam Turbine

SWCC: Saline Water Conversion Cooperation

$\mathrm{T} \mathrm{CO}_{2 \mathrm{e}}$ : Metric Tons of Carbon Dioxide Equivalent

WW: Wastewater

WWTP: Wastewater Treatment Plant 